\title{
EVALUATION OF THE AWARENESS OF THE PHYSICIANS ON NEGLIGENCE AND ABUSE OF THE ELDERLY PATIENTS ADMITTED TO EMERGENCY DEPARTMENT
}

\author{
Saffet Özdemir', Burak Katıpoglu' ${ }^{1}$ Togay Evrın', Fatma Akkus Özdemir ${ }^{2}$, \\ Eylem Kuday Kaykısız ${ }^{3}$, Zamir Kemal Ertürk', Sınan Cem Uzunget ${ }^{1}$, Atilla Korkmaz ${ }^{1}$ \\ ${ }^{1}$ Department of Emergency Medicine, UFuK University Medical Faculty, Dr Ridvan Ege Education and Research Hospital, Ankara, Turkey \\ ${ }^{2}$ Department of Child and Adolescent Mental Health, Ankara Research and Trainig Hospital, Turkey \\ ${ }^{3}$ Bitlis State Hospital, Bitlis State Hospital Department of Emergency Medicine 13000 Bitlis/Turkey, 13000 Bitlis, Turkey \\ ${ }^{4}$ Department of Emergency Medicine, Kirsehir Ahi Evran University Faculty of Medicine, Turkey
}

\begin{abstract}
INTRODUCTION: With the increase in the population of the elderly, the negligence and abuse of the elderly (NAE) is increasing at a great pace. Although the rates of NAE in the elderly admitted to emergency department (ED) is more than the estimated rates, the diagnosis and reporting of such cases are extremely rare. The primary aim of the present study is to evaluate the NAE status in the elderly admitted to ED, the awareness in ED physicians, the attitudes towards these cases and the knowledge levels in this field.

METHODS: An electronic questionnaire form that was used as the data collection tool consisted of 19 questions and 2 sections. To call for participation, the questionnaires used in the study were shared with the ED physicians in an online manner between December 2017 and April 2018. The data were analyzed with the SPSS 23.0 Windows computer program with definitive statistics.
\end{abstract}

RESULTS: A total of $69.4 \%$ of the participants faced NAE and $30 \%$ did not report this; $79.8 \%$ of the participants stated that they had received training in this field and $9 \%$ stated that there was a screening test for the abuse of the elderly. A statistically significant difference was determined between those who received course training in this field and those who received training during medicine faculty education and specialist training.

CONCLUSIONS: In this study, it was observed that the NAE rates were more than the estimated rates in the elderly admitted to ED. It was understood that ED physicians did not have adequate knowledge in this field. A new curriculum is needed for the training and education in this field.

KEY WORDS: elderly and terminally ill, abuse, negligence, emergency medicine.

Disaster Emerg Med J 2018; 3(3): 82-90

\section{INTRODUCTION}

Old age has been accepted as being dependent in terms of health, being less productive in terms of work life, and being at and above the age of 65 in terms of age [1]. With the increasing population of the elderly, the negligence and abuse of the elderly by their relatives or by people who take care of them appear before us as an increasing problem [2]. The International Network for the Prevention of Elder Abuse and the $\mathrm{WHO}$ released the Toronto 
Declaration in 2002 and defined the abuse of the elderly as "The damage given to any elderly who expect trust, and the inappropriate actions that occur once or repeatedly causing stress in the elderly, or the lack of the appropriate behaviors" $[3,4]$. The negligence of the elderly is defined as "Not giving the things needed by the elderly such as food, beverages, drugs by their relatives or caregivers, with or without awareness, and behaving in a careless way in fulfilling the responsibilities for the elderly or not fulfilling such responsibilities at all" [5]. NAE is one of the important mortality and morbidity reasons [6-8]. Healthcare employees, especially emergency department (ED) physicians should be careful in detecting this condition [9]. Several tests were developed in the past to detect the elderly abuse [10, 11]. The Hwalek-Sengstock Elder Abuse Screening Test is one of these tests, which measure direct abuse, vulnerability and situational characteristics. It is the most appropriate test for using in hospitals and can be easily applied in a short time period by emergency trauma physicians, geriatricians and even by assistant health staff $[12,13]$.

Due to many reasons like long-term policlinic appointments, inadequate healthcare staff, and uninterrupted service of ED, the elderly are taken to ED by their relatives, caregivers or by nursing homes. The excessive intensity in ED, the lack of knowledge in health employees and inadequacy of ED conditions cause that the NAE cases go undetected; and only when there is serious doubt can they be recognized.

The main purpose of this study is to evaluate the awareness and attitudes and knowledge levels of the emergency physicians on NAE in elderly patients who are admitted to ED. Meanwhile, it was also aimed to raise the awareness levels on NAE cases by physicians working in ED. It is important to identify and report the factors affecting NAE, and to take precautions and initiatives to prevent it.

\section{METHODS \\ The Universe and Sampling Selection}

Our study is a descriptive study; and was designed as a survey study. The Ethical Board Approval for the study was obtained from Ufuk University, Faculty of Medicine with the number 20171207-6. Emergency medicine academicians, professionals, assistants and general practitioners working at EDs, university hospitals across Turkey, training and research hospitals, state hospitals and private hospitals constitute the universe of the study; and for this reason, it is not known for sure how many people constitute the universe of the study. Since the number of the people in the universe is not known, the number of the sampling was computed with the $N=\left(t_{1-a}\right)^{2} x(p x q)^{2} / S^{2}$ formula [14]. The questionnaire was planned to be conducted between December 2017 and April 2018, and when the number of the adequate participants was reached (500 people), the questionnaire application was ended in February 2018. The ED physicians who could be contacted through the Internet and who agreed to participate in the study were included in the study. Those who could not be contacted through e-mails and who did not agree to participate in the study were excluded from the study.

\section{The Scales Used in the Study}

The electronic questionnaire, which was created by using the data collection tool, consisted of two titles, which were the Sociodemographic Form and the Questionnaire Form. A total of 19 questions were prepared. Some of the questions had 4-Point Likert-type answers. In the Sociodemographic Data Form, the gender, age, occupational status, institution worked, duration of ED work, the number of patients and the number of the elderly patients who were admitted daily, the percentage of abuse and neglect in the elderly applicants, whether they had received any training related to NAE and whether they followed the up-to-date developments, and if they did, how they followed the up-to-date data on this topic were questioned. The following fields were also questioned in the questionnaire; whether or not they faced NAE before; at which stage they diagnosed NAE; whether or not they received training on NAE; the risk factors in the patients in terms of NAE; whether or not they questioned the 14 items of the Hwalek-Sengstock Screening Test in patients who were suspected in terms of NAE; whether or not they had the NAE screening test; and NAE anamnesis and physical examination findings (23 items); which method they applied when they faced NAE; why the NAE reporting was low; and why such cases were not reported.

\section{The Data Analysis and Statistical Methods}

The collected data were recorded in SPSS 23 program and were then analyzed statistically. The descriptive data are given as the number of the participants and percentages. The normal distribution fit- 
ness of the variables was examined using the Visual (Histogram and Probability Graphics) and Analytical Methods (Kolmogorov-Smirnov/Shapiro-Wilk tests). The median, 25-75 percentile, and minimum-maximum values were used as descriptors for non-parametric tests. The Mann Whitney U-test was used as a Hypothesis Test in paired groups. The Kruskal Wallis test was used in multiple groups. $\mathrm{P}<0.05$ was taken as statistically significant.

\section{RESULTS}

A total of 316 (63.2\%) participants were male; and $49 \%(n=245)$ were between $20-30$ years of age. According to the occupational status, $34.4 \%$ were specialist doctors, $27.6 \%$ were general practitioners, $27.4 \%$ were research assistants and $10.6 \%$ were academicians. A total of $36 \%(n=180)$ worked at state hospitals; and 30,4\% $(n=152)$ had been working at ED for $2-5$ years. While the daily number of patients admitted to ED where $41 \%$ of the participants worked was over 500; the number of the patients who were over the age of 65 admitted to the ED was between $76-250$ in $41.6 \%(n=208)$ of the participants. While in $51.6 \%(n=258)$ of the patients, the percentage of those facing abuse or negligence was below $1 \%$; in $7.2 \%(n=36)$, this rate was above $10 \%$. When the place where the participants received training on the negligence and abuse of the elderly was questioned, it was determined that $39.4 \%(n=197)$ received this training during their education at the medicine faculty; the others received it during specialization training and at courses; and $19.8 \%(n=99)$ did not receive any training at all (Tab. 1).

Statistically significant differences were determined in terms of the awareness levels in the comparisons to the risk factors of the participants who received and who did not receive training, and HSEAST and awareness both in terms of the risk factors and in anamnesis and FM findings $(p<0.001)$. In further examinations among the groups, it was determined in terms of the awareness of risk factors that those who received training in courses had higher awareness levels than those who did not receive any training; those who received training during specialization education had higher awareness levels than those who received this training in medical faculties; and those who received training during courses had higher awareness levels than those who received this training during medical faculty and specialist period at statistically significant levels.

\begin{tabular}{|c|c|c|c|}
\hline \multicolumn{2}{|r|}{ Characteristics } & (n) & $\%$ \\
\hline \multirow[t]{2}{*}{ Sex } & male & 316 & 63,2 \\
\hline & female & 184 & 36,8 \\
\hline \multirow[t]{4}{*}{ Age } & $20-30$ & 196 & 39,2 \\
\hline & $31-40$ & 245 & 49 \\
\hline & $41-50$ & 49 & 9,8 \\
\hline & $>50$ & 10 & 2 \\
\hline \multirow[t]{4}{*}{ Status } & physician & 138 & 27,6 \\
\hline & research assistance & 137 & 27,4 \\
\hline & emergency medicine specialist & 172 & 34,4 \\
\hline & Lecturer & 53 & 10,6 \\
\hline \multirow[t]{4}{*}{ Institution } & State hospital & 180 & 36 \\
\hline & research and training hospital & 132 & 26,4 \\
\hline & university hospital & 168 & 33,6 \\
\hline & other & 20 & 4 \\
\hline \multirow{4}{*}{$\begin{array}{l}\text { Work } \\
\text { duration } \\
\text { for ED }\end{array}$} & $<1$ age & 122 & 24,4 \\
\hline & $2-5$ ages & 152 & 30,4 \\
\hline & $6-10$ ages & 132 & 26,4 \\
\hline & $>10$ age & 94 & 18,8 \\
\hline \multirow{4}{*}{$\begin{array}{l}\text { The } \\
\text { number } \\
\text { of daily } \\
\text { patient } \\
\text { admissions }\end{array}$} & $0-50$ & 14 & 2,8 \\
\hline & $51-150$ & 107 & 21,4 \\
\hline & $151-500$ & 174 & 34,8 \\
\hline & $>500$ & 205 & 41 \\
\hline \multirow{4}{*}{$\begin{array}{l}\text { The } \\
\text { number } \\
\text { of daily } \\
\text { patient } \\
\text { over } 65 \\
\text { admissions }\end{array}$} & $0-25$ & 65 & 13 \\
\hline & $26-75$ & 163 & 32,6 \\
\hline & $76-250$ & 208 & 41,6 \\
\hline & $>250$ & 64 & 12,8 \\
\hline \multirow{4}{*}{$\begin{array}{l}\text { Percentage } \\
\text { of abuse } \\
\text { and } \\
\text { neglect } \\
\text { likelihood } \\
\text { reported } \\
\text { by elderly } \\
\text { patients }\end{array}$} & $\% 0-1$ & 258 & 51,6 \\
\hline & $\% 2-5$ & 152 & 30,4 \\
\hline & $\% 6-10$ & 54 & 10,8 \\
\hline & $>\% 10$ & 36 & 7,2 \\
\hline \multirow{4}{*}{$\begin{array}{l}\text { Education } \\
\text { status } \\
\text { about EAN }\end{array}$} & faculty of medicine & 197 & 39,4 \\
\hline & during the reseach assistantship & 98 & 19,6 \\
\hline & via a course education & 106 & 21,2 \\
\hline & No education & 99 & 19,8 \\
\hline \multicolumn{2}{|l|}{ Total } & 500 & 100 \\
\hline
\end{tabular}

EAN: Elder Abuse and Neglect.

In terms of the awareness on anamnesis and FM findings, it was determined that those who received training with courses had the highest-level awareness; and those who received training during 


\begin{tabular}{|c|c|c|c|c|}
\hline \multicolumn{5}{|c|}{ Awareness about history and physical examination findings of EAN } \\
\hline EAN education & $\begin{array}{l}\text { median } \\
\text { (25-75per) }\end{array}$ & $p$ value & comparison in subgroups & $\mathrm{p}$ value \\
\hline \multirow[t]{2}{*}{ faculty of medicine (1) } & \multirow[t]{2}{*}{$72(64-81)$} & \multirow{6}{*}{$<0,001$} & $4-1$ & 0,760 \\
\hline & & & $4-2$ & 0,020 * \\
\hline research assitantship (2) & $76(68-82)$ & & $4-3$ & $<0,001$ \\
\hline course (3) & $79(75-83)$ & & $1-2$ & 0,017 * \\
\hline \multirow[t]{2}{*}{ no education (4) } & \multirow[t]{2}{*}{$72(65-80)$} & & $1-3$ & $<0,001$ \\
\hline & & & $2-3$ & $0,009^{*}$ \\
\hline \multicolumn{5}{|c|}{ Awareness about HS-EAST scale } \\
\hline education about EAN & $\begin{array}{c}\text { median } \\
(25-75 \text { per })\end{array}$ & $\mathrm{p}$ value & comparison of subgroups & $\mathrm{p}$ value \\
\hline \multirow[t]{2}{*}{ faculty of medicine (1) } & \multirow[t]{2}{*}{$28(21-36)$} & \multirow{6}{*}{$<0,001$} & $4-1$ & 1,000 \\
\hline & & & $4-2$ & 0,072 \\
\hline research assitantship (2) & $31(27-38)$ & & $4-3$ & $<0,001$ \\
\hline course (3) & $46(44-48)$ & & $1-2$ & 0,073 \\
\hline \multirow[t]{2}{*}{ no education (4) } & \multirow[t]{2}{*}{$27(20-36)$} & & $1-3$ & $<0,001$ \\
\hline & & & $2-3$ & $<0,001$ \\
\hline
\end{tabular}

EAN: Elder Abuse and Neglect, HS-EAST: Hwalek-Sengstock Elder abuse screening test ${ }^{*} \mathrm{p}<0,05$

specialization training were more aware than those who received training during medicine faculty and those who did not receive any training at a statistically significant level $(p<0.001)$. In terms of the awareness of anamnesis and FM findings, no statistically significant differences were determined between those who did not receive training and those who received training during the education at medicine faculty. When the data were analyzed in terms of the awareness on HT-EAST Scale, the awareness of those who received training in courses was higher than the other groups at a statistically significant level $(p<0.001)$. No statistically significant differences were determined in the comparisons of other sub-groups ( $p>0.05$ ) (Tab. 2).

When the relation between the awareness on NAE risk factors, anamnesis and physical examination findings and HS-EAST scale and the duration of working at ED was examined, it was determined that the awareness of those who worked in ED for 6-10 years and more than 10 years was more than those who had a working duration of $<1$ year and those $>10$ years and those whose working durations were $2-5$ years at a statistically significant level $(p<0.001)$. No statistically significant differences were detected between the other subgroups ( $p>0.05$ ). No significant differences were determined either in terms of the risk factors and the awareness on HS-EAST scale ( $p>0.05)$ (Tab. 3).

The relation between the awareness of NAE anamnesis and physical examination findings and the working status was examined, and it was determined that there was a statistically significant difference between the academicians and specialist doctors and research assistant doctors and general practitioners $(p<0.001)$. No statistically significant effect was determined in terms of working status relation between the risk factors and the HS-EAST scale awareness ( $p>0.05)$ (Tab. 4).

In our study, the risk factors of the NAE, the genders of the participants, the working durations at ED, and working status of the participants were compared; however, no statistically significant differences were detected.

When the route to be taken in case NAE was faced was analyzed, it was determined that $70 \%$ of the participants said "I would report this"; and 13\% said "I am indecisive". The reasons for not reporting are given in Table 5 (Tab. 5).

\section{DISCUSSION}

According to a compilation on elderly abuse, 10\% of the elderly are exposed to abuse in the USA. In 
Table 3. Comparison of participants awareness about risk factors, history and physical examination findings of EAN and HS-EAST scale in terms of work duration for emergency department

\section{Awareness about history and physical examination findings of EAN}

\begin{tabular}{|c|c|c|c|c|}
\hline \multicolumn{5}{|c|}{ Awareness about history and physical examination findings of EAN } \\
\hline $\begin{array}{l}\text { work duration } \\
\text { (years) }\end{array}$ & $\begin{array}{c}\text { median } \\
\text { (25-75per) }\end{array}$ & $\mathrm{p}$ value & comparison of subgroups & $\mathrm{p}$ value \\
\hline \multirow[t]{3}{*}{$<1$ year } & \multirow[t]{3}{*}{$72(64-78)$} & \multirow{7}{*}{$<0,001$} & $<1$ year and $2-5$ years & 0,231 \\
\hline & & & $<1$ year and $6-10$ years & $<0,001$ \\
\hline & & & $<1$ years and $>10$ years & $<0,001$ \\
\hline \multirow[t]{2}{*}{$2-5$ years } & \multirow[t]{2}{*}{$75(65-81,5)$} & & $2-5$ years and $6-10$ years & 0,297 \\
\hline & & & $2-5 y e a r s$ and $>10$ years & $<0,001$ \\
\hline $6-10$ years & $77(69,5-82)$ & & \multirow[t]{2}{*}{$6-10$ years and $>10$ years } & \multirow[t]{2}{*}{0,687} \\
\hline$>10$ years & $79(72-85)$ & & & \\
\hline
\end{tabular}

HS-EAST: Hwalek-Sengstock Elder Abuse Screening Test

Table 4. Comparison of participants awareness about risk factors, history and physical examination findings of EAN and HS-EAST scale in terms of their grades.

\begin{tabular}{|c|c|c|c|c|}
\hline \multicolumn{5}{|c|}{ Awareness about history and physical examination findings of EAN } \\
\hline grade & $\begin{array}{c}\text { median } \\
\text { (25-75per) }\end{array}$ & $p$ value & comparison fo subhroups & $p$ value \\
\hline \multirow{3}{*}{$\begin{array}{l}\text { physician } \\
\text { (1) }\end{array}$} & \multirow[t]{3}{*}{$72(65-79)$} & \multirow{6}{*}{$<0,001$} & $1-2$ & 1,000 \\
\hline & & & $1-3$ & $<0,001$ \\
\hline & & & $1-4$ & $<0,001$ \\
\hline $\begin{array}{l}\text { research assistant } \\
(2)\end{array}$ & $73(64-81)$ & & $2-3$ & $<0,001$ \\
\hline $\begin{array}{l}\text { emergency medicine specialist. } \\
\text { (3) }\end{array}$ & $78(72-84)$ & & $2-4$ & $<0,001$ \\
\hline $\begin{array}{l}\text { lecturer } \\
\text { (4) }\end{array}$ & $80(69-84)$ & & $3-4$ & 1,000 \\
\hline
\end{tabular}

HS-EAST: Hwalek -Sengstock Elder Abuse Screening Test

the same study it was determined that the elderly abuse was detected in Ireland (2.2\%) with the least level; and in Croatia (61.1\%) with the highest level in European countries. In Asian countries, the elderly abuse was detected at the highest level in China (36.2\%) and at the lowest level in India (14\%) [15]. In our study, when the rate of NAE was questioned in the elderly patients who applied to ED; $82 \%$ of the participants answered that the rate was below 5\%. According to the results of epidemiological studies in Turkey and in the world, these rates are expected to grow much higher in the future. When the results of similar studies in the literature were analyzed, it was determined that health professionals, especially physicians, do not know exactly how often they faced $N A E$, and therefore little was known about the $\operatorname{NAE}[16,17]$. One of the reasons is that there may be a large number of patients admitted to ED ( $41 \%$ of the participants in our study had 500 and more patients, and 34.8\% had between 151 and 500 patients). Many previous studies pointed out that the Emergency Medicine training program provides very little information on the needs and diseases of the elderly population and that Emergency Medicine Specialists did not receive adequate training in this field [18-26]. Similar studies investigated the level of knowledge, attitudes and behaviors towards $N A E$, and it was understood that there are many missing points in the diagnosis of NAE and how to act on the subject. In these studies, the participants reported that they had not received adequate and effective training [17, 27-31]. In our study, $81.2 \%$ of the participants stated that they were trained about the subject; however, $71 \%$ of them did not follow the up-to-date developments in the field. The reason why the training rates were so high in the study may be that it did not specify the educational framework when questioning the training of the participants. 


\begin{tabular}{|c|c|c|}
\hline & $\begin{array}{c}\text { number of } \\
\text { participants }(n)\end{array}$ & $\begin{array}{c}\text { percent } \\
(\%)\end{array}$ \\
\hline \multicolumn{3}{|l|}{ Ways to follow in EAN } \\
\hline 1.only clinical intervention is available & 6 & 1,2 \\
\hline 2.the family is warned and given suggestions & 59 & 11,8 \\
\hline 3. I report EAN as judicial case & 237 & 47,4 \\
\hline 4.unstable & 65 & 13 \\
\hline $2+3$ & 63 & 12,6 \\
\hline $1+2$ & 20 & 4 \\
\hline $1+3$ & 50 & 10 \\
\hline \multicolumn{3}{|l|}{ Reasons for not reporting EAN } \\
\hline I believe that physicians are adequately protected against the problems that may arise in these matters. & 53 & 10,6 \\
\hline I can not find enough time to evaluate these patients in emergency department conditions. & 136 & 27,2 \\
\hline I do not have enough knowledge and / or experience in this regard. & 117 & 23,4 \\
\hline I do not want to neglect the patient-physician & 9 & 1,8 \\
\hline $\begin{array}{l}\text { The risk of worsening of the current conditions of the patient (family relationship...) / the patient does } \\
\text { not want this condition to be known }\end{array}$ & 50 & 10 \\
\hline Others & 15 & 3 \\
\hline$A+B$ & 46 & 9,2 \\
\hline$B+E$ & 66 & 13,2 \\
\hline$C+E$ & 8 & 1,6 \\
\hline Total & 500 & 100 \\
\hline
\end{tabular}

EAN: Elder Abuse and Neglect

The relationship between the awareness and working status of the NAE anamnesis and physical examination findings was examined; and it was determined that academicians and specialist doctors, research assistants, doctors and general practitioners were more aware of this field. When the relationship between the awareness of the anamnesis and the physical examination findings was investigated in relation to the working duration in ED, it was determined that the awareness of this field increased accordingly to the duration of working at ED. This data suggests that medical school education is inadequate in this context. Not having adequate training and knowledge on the anamnesis and FM in the basic point can cause wrong intervention and is a condition that must be taken seriously. Anamnesis is the most important step in considering the abuse and neglect of the elderly [31].

If we compare where the training was conducted with the NAE risk factors and the awareness of the Hwalek-Sengstock scale, a statistically significant difference was detected between the training courses, the training groups and the other groups. Emergency medicine specialists and academicians may have increased awareness levels because of their clinical experience and their own initiatives. It is obvious that there is a theoretical inadequacy in the faculty of medicine, and in the curricula of the specialization trainings. In this respect, there is a need to revise and organize the relevant trainings and increase the productivity. In the study, the risk factors of the NAE with the gender of the participants, the working duration in ED and the working status were compared; however, no significant differences were detected. One of the risk factors for the elderly people in NAE is the attractive financial resources of the elderly patients [32-34]. This was questioned in our study; and a small number of participants said "The socioeconomic status being high is a risk factor in NAE". Additionally, when the data of the study were analyzed, and when it was considered that there is a high probability of diagnosing the NAE by "general appearance" and "physical examination", emergency physicians take the physical examination findings 
into account in most cases and recognize physical abuse. For this reason, economic abuse may go undetected and since they do not have adequate training in this field, they may not notice economic abuse.

In a study by Austin and Rinker [35], physical examination findings which showed abuse at the highest rate were reported as abrasion-like lesions in the skin, decubitus ulcers, and burns. Similar answers were received in our study by the participants with similar physical findings as "highly doubtful" and "moderately suspicious". When the participants were examined in terms of how they diagnosed NAE when they faced it, it was determined that the participants mostly diagnosed the cases with anamnesis, physical examination and general appearance.

The question "Is there a valid and reliable screening test for the elderly abuse?" was asked to the participants in our study; and 9\% said "Yes". In the questionnaire used in the present study, the Hwalek-Sengstock Elderly Abuse Screening Test (HS-EAST) consisting of 14 questions was asked. The participants who answered questions about direct abuse and potential abuse answered as "frequently ask" and "certainly ask" below $50 \%$. This suggests that the questions that might detect the direct abuse in the screening test and possible abuse are not asked; and therefore, there is a possibility of such cases being undetected. The HS-EAST awareness and working status were compared and it was determined that there was no statistically significant difference between them. This result suggests that there is little awareness of the screening test, no matter how long the working status is. When we compared the educational status and the awareness on HSEAST, there was a significant difference between the course trainees and other groups. The inclusion of the abovementioned test in the curricula of medical faculties and in the specialist training programs may increase the awareness in this field because the test has this feature, and this may ensure that such patients are detected and not neglected.

It is seen that in the studies conducted previously, health professionals, especially physicians, are not aware of relevant laws and regulations, and medical protocols that will inform them about NAE $[16,31$, 36]. Dong [37] conducted a study and reported that only 1 out of 14 cases reported such cases in NAE. In the study of Mandıracıoğlu et al. [27], most of the participants stated that they did not know what to do when faced with NAE. The number of those who do not report suspicious cases in our work is too high to be neglected (30\%). On the other hand, NAE causes significant mortality and morbidity, together with psychosocial problems in the elderly [15] (Referans 15 otomatik olarak alınmamış). When it is analyzed why the participants did not report such cases, there may be many reasons such as excessive workload due to the intensity of the ED, not knowing relevant laws, not feeling self-sufficient about NAE, and increasing violence towards health employees in recent years by the relatives of patients.

\section{CONCLUSION}

As a result, we determined that course EA awareness was higher in the NAE case in theoretical field than the other groups (the risk factors, HS-EAST, etc.). While the course EA awareness in NAE cases in practical field (anamnesis and FM findings) is higher than the EA during the specialist training, the lowest awareness was determined in those who did not receive $E A$ and education in medicine faculty was similar, which shows the importance of education. It must be taken seriously because there are missing points in the anamnesis and FM, which are the most basic steps of the education taken in the medical faculties. Considering the scientific studies on NAE in many countries, particularly in the United States, which started many years ago, it is possible to claim that the development in protective and preventive measures are in early stages in Turkey. For this reason, we want to emphasize the need for different studies on this population for future research.

Funding and support: No funding was received.

Conflict of interest: All authors declare that they have no conflict of interest.

Author Contributions: S.O. performed the study design, data collection and analysis, and article's drafting; B.K. study design, analysis and article's drafting; and T.E. study design, data collection, F.A.O. article's drafting; E.K.K. article drafting, Z.K.E. study design and article's drafting, S.C.U. data collection, A.K. analysis and article's drafting and all authors contributed substantially to its revision and approved the final version of the study.

\section{REFERENCES}

1. Kutsal G. Yaşlanan dünyanın yaşlanan insanları. Temel Geriatri, Geriatri Derneği yayını, Ankara 2008. 
2. Keskinoğlu P. Yaşııda fiziksel, finansal örselenme ve ihmal edilme. Türk Geriatri Dergisi. 2004; 7(2): 57-61.

3. Organization, W.H. The Toronto declaration on the global prevention of elder abuse. Geneva: WHO. 2002: 3.

4. Organization, W.H. World report on ageing and health. World Health Organization 2015.

5. Acierno R, Hernandez MA, Amstadter $A B$, et al. Prevalence and correlates of emotional, physical, sexual, and financial abuse and potential neglect in the United States: the National Elder Mistreatment Study. Am J Public Health. 2010; 100(2): 292-297, doi: 10.2105/ AJPH.2009.163089, indexed in Pubmed: 20019303.

6. Uysal A, Dünyada yaygın bir sorun: yaşıı istismarı ve ihmali. Sosyal Politika Çalışmaları Dergisi. 2002; 5(5).

7. Oh J, Kim H, Martins D, et al. A study of elder abuse in Korea. International Journal of Nursing Studies. 2006; 43(2): 203-214, doi: 10.1016/j.jijnurstu.2005.03.005.

8. Dyer CB, Connolly M-T, McFeeley P. The clinical and medical forensics of elder abuse and neglect. 2003.

9. Tierney MC, Snow WG, Charles J, et al. Neuropsychological predictors of self-neglect in cognitively impaired older people who live alone. Am J Geriatr Psychiatry. 2007; 15(2): 140-148, doi: 10.1097/01. JGP.0000230661.32735.c0, indexed in Pubmed: 17272734.

10. Reis $M$, Nahmiash D. Validation of the indicators of abuse (IOA) screen. Gerontologist. 1998; 38(4): 471-480, indexed in Pubmed: 9726134.

11. Fulmer $T$, et al. Elder neglect assessment in the emergency department. Journal of Emergency Nursing. 2000; 26(5): 436-443, doi: $10.1067 /$ men.2000.110621.

12. Ozmete E. The Hwalek-Sengstock Elder Abuse Screening Test: The adaptation study into Turkish. Anatolian Journal of Psychiatry. 2016; 17(1): 45, doi: 10.5455/apd.200727.

13. Özçakar N, Toprak Ergönen A, Kartal M, et al. Adaptation, reliability, and validity study of the Hwalek-SengstockElder Abuse Screening Test (H-S/EAST): a Turkish version. Turk J Med Sci. 2017; 47(6): 1894-1902, doi: 10.3906/sag-1606-166, indexed in Pubmed: 29306255.

14. Tezcan S. Epidemiyoloji: tıbbi araştırmaların yöntem bilimi. Hacettepe Halk Sağlı̆ı Vakf. 1992.

15. Dong XQi. Elder Abuse: Systematic Review and Implications for Practice. J Am Geriatr Soc. 2015; 63(6): 1214-1238, doi: 10.1111/ jgs. 13454, indexed in Pubmed: 26096395.

16. Almogue A, Weiss A, Marcus EL, et al. Attitudes and knowledge of medical and nursing staff toward elder abuse. Arch Gerontol Geriatr. 2010; 51(1): 86-91, doi: 10.1016/j.archger.2009.08.005, indexed in Pubmed: 19775762.

17. Kennedy RD. Elder abuse and neglect: the experience, knowledge, and attitudes of primary care physicians. Fam Med. 2005; 37(7): 481-485, indexed in Pubmed: 15988632.

18. Arai $H$, Ouchi $Y$, Yokode $M$, et al. Members of Subcommittee for Aging. Toward the realization of a better aged society: messages from gerontology and geriatrics. Geriatr Gerontol Int. 2012; 12(1): 16-22, doi: 10.1111/j.1447-0594.2011.00776.x, indexed in Pubmed: 22188494.
19. Sinha SK, Bessman ES, Flomenbaum N, et al. A systematic review and qualitative analysis to inform the development of a new emergency department-based geriatric case management model. Ann Emerg Med. 2011; 57(6): 672-682, doi: 10.1016/j.annemergmed.2011.01.021, indexed in Pubmed: 21621093.

20. Wilber ST, Gerson LW, Terrell KM, et al. Geriatric emergency medicine and the 2006 Institute of Medicine reports from the Committee on the Future of Emergency Care in the U.S. health system. Acad Emerg Med. 2006; 13(12): 1345-1351, doi: 10.1197/j.aem.2006.09.050, indexed in Pubmed: 17071799.

21. Biese KJ, Roberts E, LaMantia M, et al. Effect of a geriatric curriculum on emergency medicine resident attitudes, knowledge, and decision-making. Acad Emerg Med. 2011; 18 Suppl 2: S92-S96, doi: 10.1111/j.1553-2712.2011.01170.x, indexed in Pubmed: 21999564.

22. Prendergast HM, Jurivich D, Edison M, et al. Preparing the front line for the increase in the aging population: geriatric curriculum development for an emergency medicine residency program. J Emerg Med. 2010; 38(3): 386-392, doi: 10.1016/j.jemermed.2008.05.003, indexed in Pubmed: 19028039.

23. Carpenter CR, Shah MN, Hustey FM, et al. High yield research opportunities in geriatric emergency medicine: prehospital care, delirium, adverse drug events, and falls. J Gerontol A Biol Sci Med Sci. 2011; 66(7): 775-783, doi: 10.1093/gerona/glr040, indexed in Pubmed: 21498881.

24. Foo CL, et al. Profiling acute presenting symptoms of geriatric patients attending an urban hospital emergency department. Annals Academy of Medicine Singapore, 2009. Ann Acad Med Singapore. 2009; 38(6): 515, indexed in Pubmed: 19565102.

25. Shah MN, Bazarian JJ, Lerner EB, et al. The epidemiology of emergency medical services use by older adults: an analysis of the National Hospital Ambulatory Medical Care Survey. Acad Emerg Med. 2007; 14(5): 441-447, doi: 10.1197/j.aem.2007.01.019, indexed in Pubmed: 17456555.

26. Reuben DB, Bachrach PS, McCreath $\mathrm{H}$, et al. Changing the course of geriatrics education: an evaluation of the first cohort of Reynolds geriatrics education programs. Acad Med. 2009; 84(5): 619-626, doi: 10.1097/ACM.0b013e31819fb89d, indexed in Pubmed: 19704195.

27. Mandiracioglu A, Govsa F, Celikli S, et al. Emergency health care personnel's knowledge and experience of elder abuse in Izmir. Arch Gerontol Geriatr. 2006; 43(2): 267-276, doi: 10.1016/j.archger.2005.10.013, indexed in Pubmed: 16332396.

28. Ahmed A, Choo WY, Othman S, et al. Understanding of elder abuse and neglect among health care professionals in Malaysia: An exploratory survey. J Elder Abuse Negl. 2016; 28(3): 163-177, doi: 10.1080/089 46566.2016.1185985, indexed in Pubmed: 27149412.

29. Vetere PM. Elder abuse: what are we missing? Can Fam Physician. 2011; 57(7): 783-785, indexed in Pubmed: 21753101.

30. Kleinschmidt K. Elder Abuse: A Review. Annals of Emergency Medicine. 1997; 30(4): 463-472, doi: 10.1016/s0196-0644(97)70006-4. 
31. Jones JS, et al. Elder mistreatment: national survey of emergency physicians. Ann Emerg Med. 1997; 30(4): 473-479, indexed in Pubmed: 9326862.

32. Kissal $A$, Beser $A$. Identifying and evaluating elder abuse and neglect. TAF Prev Med Bull. 2009; 8(4): 357-364.

33. Lachs MS, Williams CS, $O^{\prime}$ Brien $S$, et al. The mortality of elder mistreatment. JAMA. 1998; 280(5): 428-432, indexed in Pubmed: 9701077.

34. Arpaci F, Bakir B. Yaşlı İstismarı ve İhmali. Journal of Social Research. 691.

35. Rinker AG. Recognition and perception of elder abuse by prehospital and hospital-based care providers. Arch Gerontol Geriatr. 2009;
48(1): 110-115, doi: 10.1016/j.archger.2007.11.002, indexed in Pubmed: 18160115.

36. Clark-Daniels C, Daniels RS, Baumhover L. Abuse and neglect of the elderly: Are emergency department personnel aware of mandatory reporting laws? Annals of Emergency Medicine. 1990; 19(9): 970-977, doi: 10.1016/s0196-0644(05)82556-9.

37. Dong X. Medical implications of elder abuse and neglect. Clin Geriatr Med. 2005; 21(2): 293-313, doi: 10.1016/j.cger.2004.10.006, indexed in Pubmed: 15804552. 